\title{
The Implementation of Weighted Products in the Support System of Scholarship Acceptance Decisions at the MA AL-Falahiyah AL-Asytari
}

\author{
Ri Sabti Septarini ${ }^{1}$, Rohmat Taufiq ${ }^{2}$, and Saiman Al Fattah ${ }^{3}$ \\ ${ }^{1,2,3}$ Informatics Departement, University of Muhammadiyah Tangerang, Jalan Perintis Kemerdekaan I \\ Babakan No.33, RT.007/RW.003, Cikokol, Kec. Tangerang, Kota Tangerang, Banten 15118 \\ e-mail: ${ }^{1}$ risabtis@ft-umt.ac.id, ${ }^{2}$ rohmat.taufiq@umt.ac.id, ${ }^{3}$ saimanalfatah212@gmail.com
}

Submitted Date: July $19^{\text {th }}, 2020$

Revised Date: December 31 $1^{\text {st }}, 2020$

\author{
Reviewed Date: September $22^{\text {nd }}, 2020$ \\ Accepted Date: January $04^{\text {th }}, 2021$
}

\begin{abstract}
Scholarships are a form of appreciation given to individuals in order to continue their education to a higher level. The scholarship program held to ease the burden on students in pursuing a period of study. Especially in matters of cost. MA Al-Falahiyah Al-Asytari organizes a scholarship program for students based on criteria determined by the school. The need for a scholarship naming decision system is one of the core needs so that the selection of scholarship acceptance is more objective and practical. Development of a Decision Support System (DSS) using the Weighted Product model chosen because it was able to select the best alternatives from several alternatives and their advantages in weighting techniques. In designing the system using Unified Modeling Language (UML) and making applications using PHP and MySQL as a database. From the research the authors have described, it concluded that the weight product method could use as one method in developing a decision support system for scholarship recipients at the MA Al-Falahiyah Al-Asytari, by inputting data from students who submit scholarships to calculating grades based on criteria which specified
\end{abstract}

Keywords: Decision Support System; Weighted Product; Scholarship Acceptance; Waterfall; UML

\section{Introduction}

School is a significant thing for human life in the absence of school, so the quality of public education in Indonesia disrupted. The life he lives will also not be guaranteed; there is much unemployment everywhere because the knowledge he has is unable to meet the desired standards. Generally, school is an educational institution that is formal, non-formal or informal, which is established by the state or private that designed to teach, educate through the education that has been given by educators. To make a school must have adequate facilities and infrastructure such as study rooms, libraries, office spaces, mosques, computer rooms or others. Besides, schools must also have programs that can support teaching and learning activities, one of which is a scholarship program.

Scholarships are a form of appreciation given to individuals in order to continue their education to a higher level. The award can be in the form of specific access to an institution or an award in the form of financial assistance (Murniasih, (2009)). Government institutions, companies or foundations can give scholarships. School-based scholarships are a work program in every school. The scholarship program held to ease the burden on students in pursuing a period of study. Especially in matters of cost. Scholarships gave to students selectively according to the type of scholarship held. Scholarships are income for those who receive and the purpose of the scholarship is to help ease the burden of the educational costs of students who get scholarships. MA Al-Falahiyah Al-Asytari is one of the madrasas at the level of senior high school in the city of Tangerang, which organizes a scholarship program for students based on criteria determined by the school. The selection process for scholarship recipients at MA Al-Falahiyah AlAsytary is still experiencing problems in the decision-making process. This is because there is no objective method to decide quickly. The need for a scholarship naming decision system is one of the core needs so that the selection of scholarship acceptance is more objective and practical.

According to Surbakti in Septarini (2017), Decision Support is defined by "Interactive 
computer-based systems that help decision-makers utilize data and models to solve unstructured problems. DSS exploits the resources of individuals intellectually with computer capabilities for management decision making related to semi-structured problems".

This system used to help make decisions in semi-structured and unstructured situations. Development of a decision support system (DSS) using the Weighted Product model chosen because it was able to select the best alternatives from several alternatives and their advantages in weighting techniques. The choice of this method based on computational complexity that is not too difficult so that the time needed to produce calculations is relatively short.

Research related to the decision support system title carried out including Taufiq \& Sugiharto (2011) research on decision support systems with multiple criteria has a positive impact on agencies, in order to accelerate and improve accuracy in the employee performance appraisal process. Taufiq et al. (2020), by using a decision support system, it will get the advantage of being easy to access, faster and more precise in the process undertaken. Septarini (2017), not only in the world of education, but decision support systems can also use in various fields, such as the calculation of the amount of production and Septarini et al. (2018) research in determining the quality of service at a workshop.

Based on the description above, this decision support system expected to provide input for schools to determine the decisions taken in selecting students who are entitled to receive scholarships based on predetermined criteria. This system also expected to overcome several problems that occur due to manual data file storage, such as the risk of substantial losses and the need for a place to store the data.

\section{Research Methods}

The research began with data collection using interviews, observation and literature studies. In designing the system using Unified Modeling Language (UML) and making applications using PHP and MySQL as a database. As for the sample of the data in this study is the data available at the MA Al-Falahiyah Al-Asytari, which includes student personal data based on the main criteria needed, as well as weighting the criteria obtained from the results of interviews and observations. The system developed in this study used the waterfall model. The depiction of the Waterfall method, according to Sommervile (2011) can see in Figure. Following the steps in the waterfall, the system development done in the following order: 1) Definition and analysis of needs; 2) System and software design; 3) Implementation and Unit testing; 4) Integration and Testing Systems; 5) Operations and maintenance

Because of it classified as practical in its implementation, this method widely used in the design of a system application.

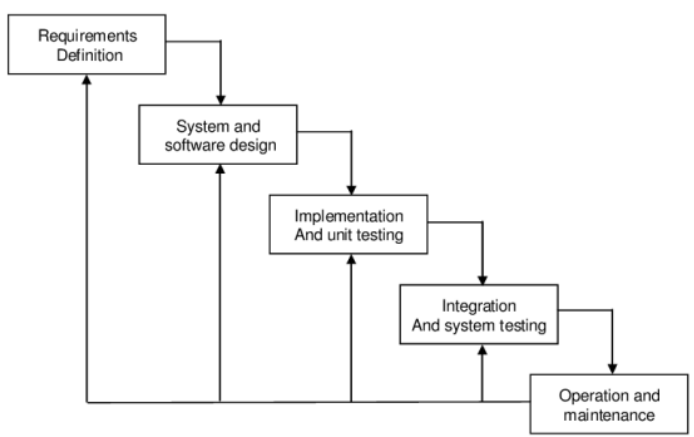

Figure 1. Waterfall Sommerville Method

In this study, it can explain that the current system at MA Al-Falahiyah Al-Asytari includes six criteria, namely the average value of the last report card, attendance, attitude and activeness in extracurricular activities. Following is the process of receiving scholarships at MA Al-Falahiyah AlAsytari.

1. Scholarship selectors provide a scholarship form to the homeroom teacher, then students who will submit the scholarship request a form.

2. After students get the scholarship form, students fill out the form entirely and signed by parents, and attach a photocopy of the latest report card grades, then collected at the homeroom teacher.

3. Homeroom teacher checks the completeness of the form; if the form filled in and the requirements are incomplete, the form is returned to students to complete again.

4. After all, forms have been collected at the homeroom teacher and completed; the scholarship forms returned to the scholarship selection team.

5. After the scholarship selectors receive the scholarship submission form, the scholarship selection team processes the selection of scholarship recipients.

6. After it has decided who is entitled to get a scholarship selection scholarship archives, the 
scholarship recipient's data and gives announcements to students.

\section{Analysis and Discussion}

\subsection{Analysis of the Current System}

Based on research conducted at $\mathrm{MA} \mathrm{Al-}$

Falahiyah Al-Asytari, it can describe as follows:

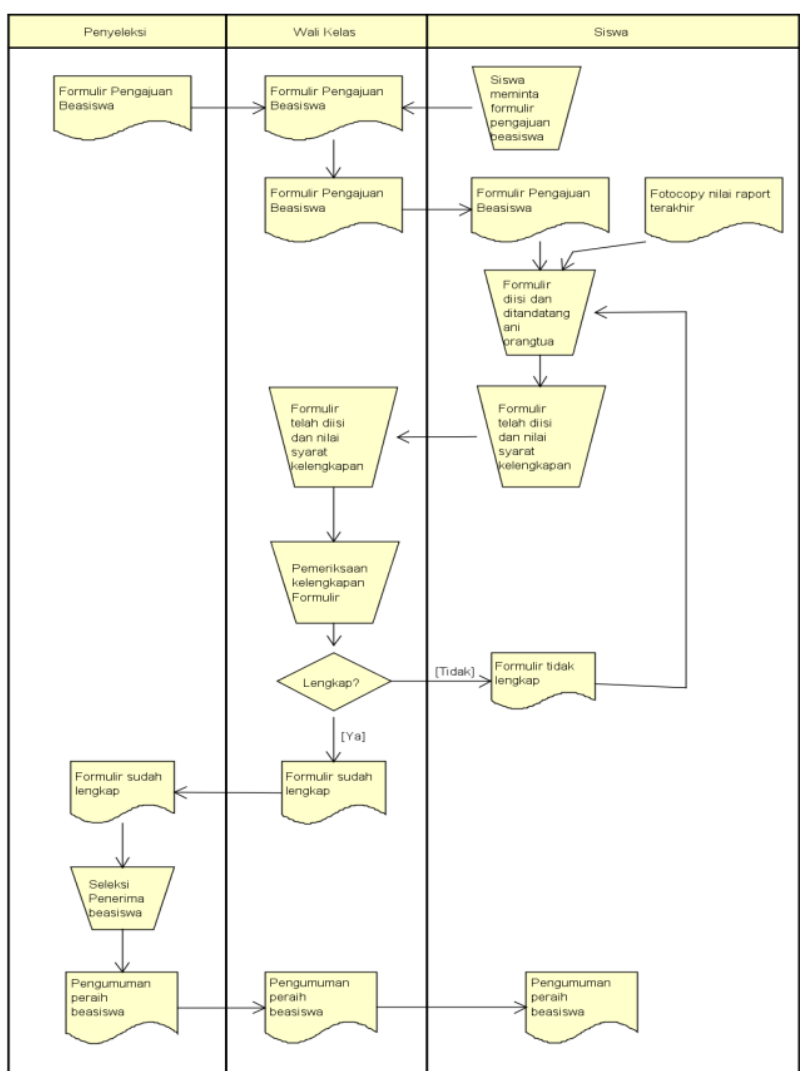

Figure 2 Current System Flowchart

\subsection{Proposed System Design}

A. System Requirements Analysis

1. Weight Product Method

In the process of the Weighted Product method, criteria needed to use as material for calculations in determining scholarships. The criteria for determining scholarships can see in the table below:

Table 1. Criteria

\begin{tabular}{|l|l|}
\hline Criteria & Information \\
\hline C1 & $\begin{array}{l}\text { Report Card Average } \\
\text { Value }\end{array}$ \\
\hline C2 & Attendance \\
\hline C3 & Attitude \\
\hline C4 & Extracurricular \\
\hline
\end{tabular}

The importance / compatibility rating of each criterion is assessed by 1 to 5 , namely: $1=$
Very Low, 2 = Low, 3 = Enough, 4 = High, $5=$ Very High

Next decision making Giving preference weight and type of criteria for each criterion as W (initial weight) can see in the following table:

Tabel 2. Weight Criteria

\begin{tabular}{|l|l|c|l|}
\hline Criteria & $\begin{array}{c}\text { Level of } \\
\text { Importance }\end{array}$ & Weight & Type \\
\hline C1 & Very high & 5 & Benefit \\
\hline C2 & Medium & 3 & Cost \\
\hline C3 & Medium & 3 & Benefit \\
\hline C4 & Low & 2 & Benefit \\
\hline
\end{tabular}

The value of each alternative in each criterion:

Table 3. Alternatives

\begin{tabular}{|l|r|r|r|r|}
\hline \multirow{2}{*}{ Alternatives } & \multicolumn{4}{|l|}{ Criteria } \\
\cline { 2 - 5 } & C1 & C2 & C3 & C4 \\
\hline Ajay Hidayat & 4 & 3 & 4 & 4 \\
\hline Junariah & 4 & 2 & 4 & 4 \\
\hline Meta Noviyanti & 3 & 3 & 4 & 4 \\
\hline M. Fajri & 4 & 1 & 4 & 4 \\
\hline Nurdianah & 4 & 2 & 4 & 4 \\
\hline S. Ramadhan & 4 & 3 & 4 & 4 \\
\hline Samsiyah & 4 & 2 & 4 & 4 \\
\hline Siti Masiroh & 3 & 3 & 4 & 4 \\
\hline Sri Tristiani & 3 & 2 & 4 & 4 \\
\hline Sutrisna & 3 & 4 & 4 & 4 \\
\hline
\end{tabular}

Perbaikkan Bobot

$$
\begin{aligned}
& W_{1}=\frac{5}{5+3+3+2}=0,38 \\
& W_{2}=\frac{4}{5+3+3+2}=0,23 \\
& W_{3}=\frac{4}{5+3+3+2}=0,23 \\
& W_{4}=\frac{2}{5+3+3+2}=0,15
\end{aligned}
$$

Then Vector $\mathrm{S}$ can be calculated as follows:

$S_{1=\left(4^{0,38}\right)\left(3^{-0,23}\right)\left(4^{0,23}\right)\left(4^{0,15}\right)=2,2543}$

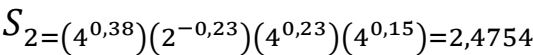

$S_{3=\left(3^{0,38}\right)\left(3^{-0,23}\right)\left(4^{0,23}\right)\left(4^{0,15}\right)=2,0182}$

$S_{4=\left(4^{0,38}\right)\left(1^{-0,23}\right)\left(4^{0,23}\right)\left(4^{0,15}\right)=2,9048}$

$S_{5=\left(4^{0,38}\right)\left(2^{-0,23}\right)\left(4^{0,23}\right)\left(4^{0,15}\right)=2,4754}$

$S_{6=\left(4^{0,38}\right)\left(2^{-0,23}\right)\left(4^{0,23}\right)\left(4^{0,15}\right)=2,4754}$

$S_{7=\left(4^{0,38}\right)\left(2^{-0,23}\right)\left(4^{0,23}\right)\left(4^{0,15}\right)=2,4754}$

$S_{8=\left(3^{0,38}\right)\left(3^{-0,23}\right)\left(4^{0,23}\right)\left(4^{0,15}\right)=2,0182}$

$S_{9=\left(3^{0,38}\right)\left(2^{-0,23}\right)\left(4^{0,23}\right)\left(4^{0,15}\right)=2,2161}$

$S_{10=\left(3^{0,38}\right)\left(4^{-0,23}\right)\left(4^{0,23}\right)\left(4^{0,15}\right)=1,8885}$ 
The Vector $\mathrm{V}$ value that will be used for ranking can be calculated as follows:

$$
\begin{array}{cc}
V_{1=\frac{2,2543}{23,2017}=0,0971} & V_{2=\frac{2,4754}{23,2017}=0,1066} \\
V_{3=\frac{2,0182}{23,2017}=0,0869} & V_{4=\frac{2,9048}{23,2017}=0,1251} \\
V_{5=\frac{2,4754}{23,2017}=0,1066} & V_{6=\frac{2,4754}{23,2017}=0,1066} \\
V_{7}=\frac{2,4754}{23,2017}=0,1066 & V_{8=\frac{2,0182}{23,2017}}=0,0869 \\
V_{9=\frac{2,2161}{23,2017}}=0,0955 & V_{10=\frac{1,8885}{23,2017}}=0,0813
\end{array}
$$

The most significant value is in V4 so that Muhammad Fajri's alternative chosen as the best alternative.

\section{Analysis of Non-Functional Needs}

The software specifications used to run this system are:
a) Windows 7 operating system
b) XAMPP
c) Browser

A. Text editor Analysis of Functional Needs The functional requirements for this system are:

a) The system can log in and log out

b) The system can create, read, update, delete criteria, sub-criteria, and alternatives

c) The system can calculate weighted products

d) The system can display the results of weighted product calculations

e) The system can change the password

f) The system can export data design

\section{1) Use Case Diagram}

In developing this system consists of a menu of criteria, sub-criteria, alternatives, and can do calculations using the weighted product method. The results gave in the form of ranking of alternatives to the criteria. Users of this system consist of the Administrator level and vice principal level, as illustrated in the Usecase diagram below.

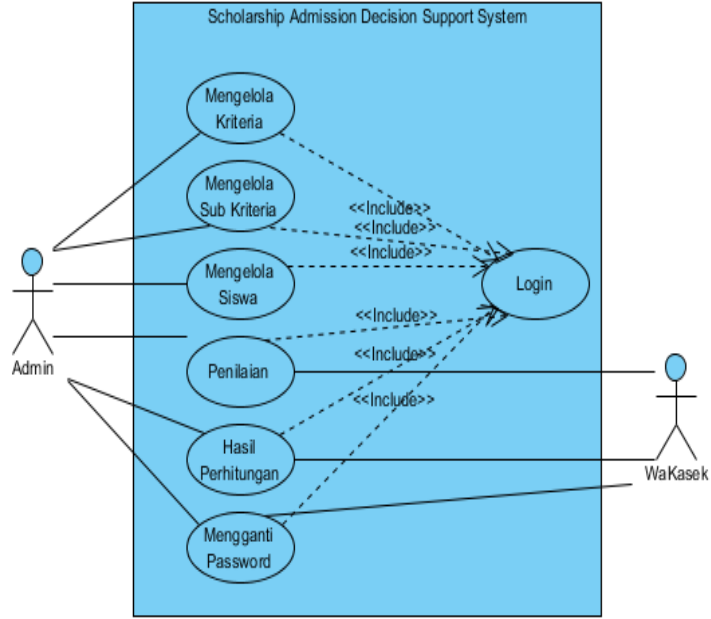

Figure 3. Use Case Diagram

The use case picture above explains the two system user users that will design. The first user is the Administrator who can manage criteria, manage sub-criteria, manage the system, make an assessment, get the calculation results, replace the password and finally log out for the second user, vice-principal. Where he can get the results of calculations, change passwords and logout. Both users must be able to access the information first by logging in.

2) Class Diagram

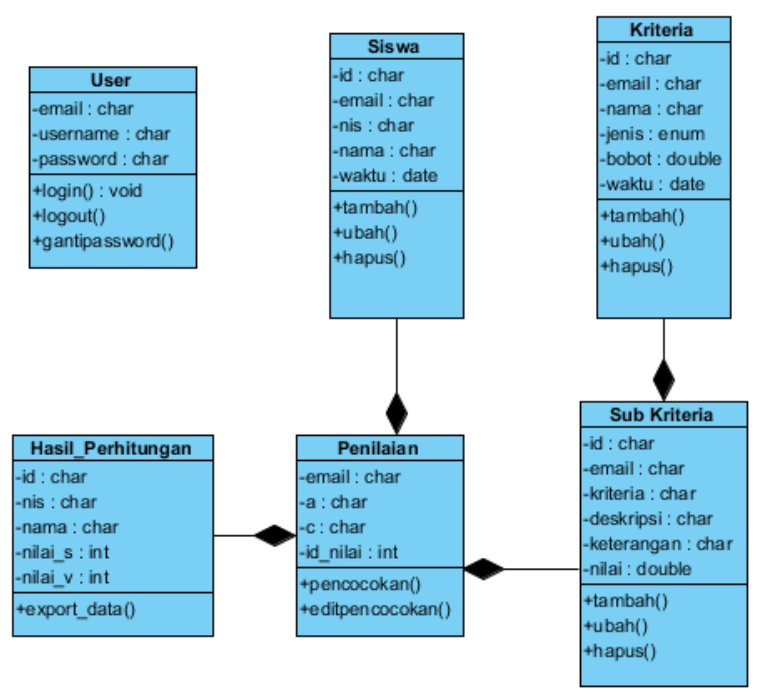

Figure 6 Class Diagram

In the class diagram, three tables are consisting of the User table, the Student table, the Criteria table, the Sub Criteria Table, the Rating table and finally the calculation table. Each table has fields that have been adjusted according to needs so that the database load is not too heavy. 
B. Implementation

1) Login

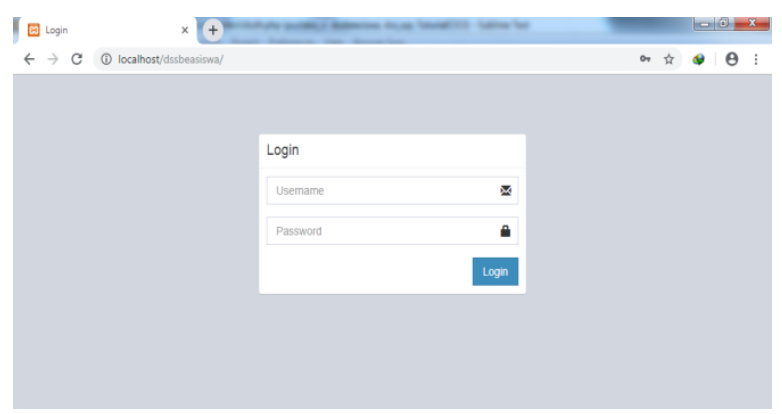

Figure 7. Login

Figure 7 above explains the user login to the system, where two users will $\log$ in to this system. The first user is the admin, and the second user is the vice-principal. After logging in if appropriate, it will go to the main page as below.

2) Dashboard

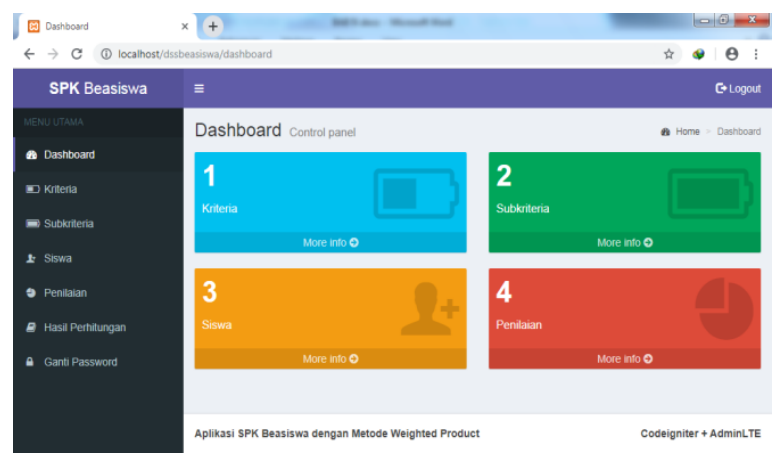

Figure 8. Dashboard

Figure 8 above is the main view where there are four links to choose. The four links are criteria, sub-criteria, students and assessment. Next on the left, there is a new calculation result menu and change the password.

\section{3) Criteria}

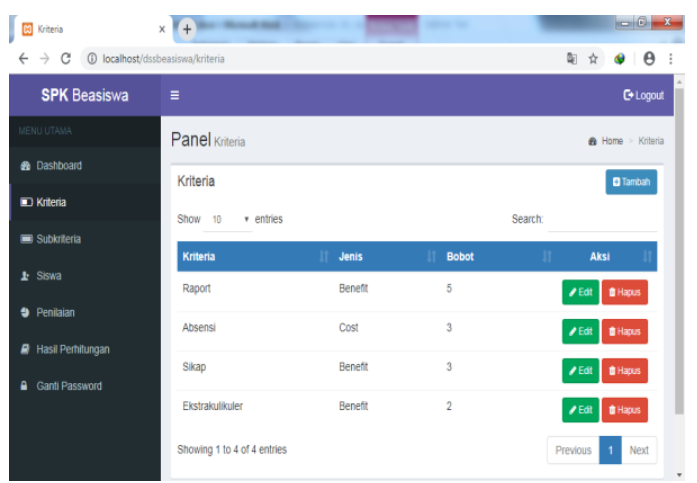

Figure 9. Criteria
Figure 9 above is a display of the form to determine the criteria and weight given. Criteria and weights that inputted, if there is an error, it can be changed by editing the menu. Alternatively, even if it does not use anymore, the criteria that have inputted can be deleted. Also, there are types of benefits or costs where it is crucial for the weighted product method.

4) Subcriteria



Figure 10. Subcriteria

Figure 10 sub-criteria above is a form that functions to input sub-criteria. The ability of the form can receive input, value and action. Student data

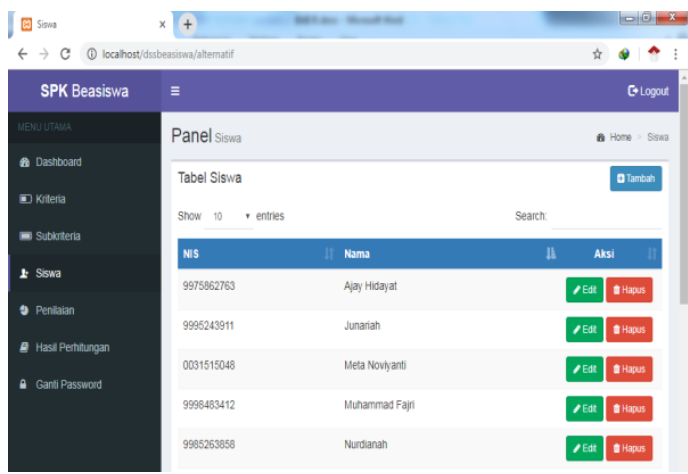

Figure 11. Student Data

The system data form above contains student data consisting of the Student Identification Number and the Last Name and column, namely action wherein this action there are two functions, namely, edit and delete. 
5) Assessment

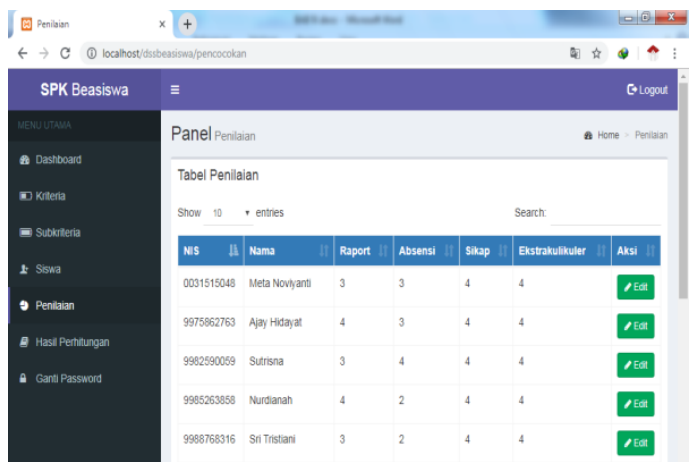

Figure 12. Assessment

Figure 12 about the assessment serves to give the value of each student. Where besides, there are student data, there is a value input consisting of report cards, attendance, attitudes, extracurricular. Each point can give a maximum value of point 5 .

6) Weight conversion

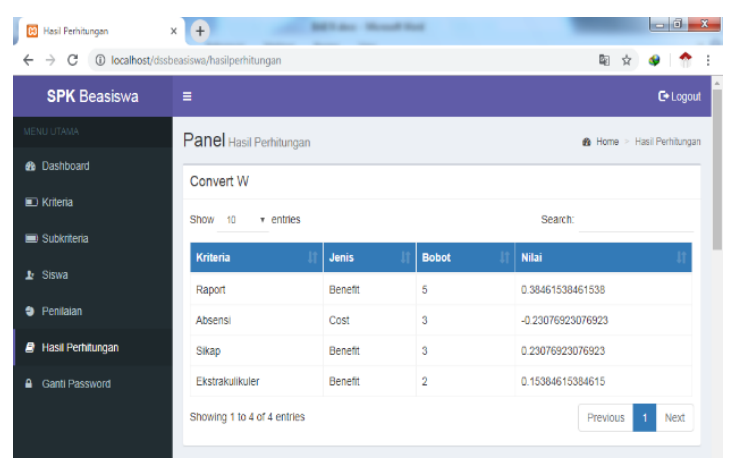

Figure 13. Weight Conversion

Weight conversion image above functions to convert from numbers that have entered. The conversion process uses the formula that is in the weighted product. From the numbers 2 or 3 or 5 after conversion, the results obtained are 0 ,

7) The calculation results

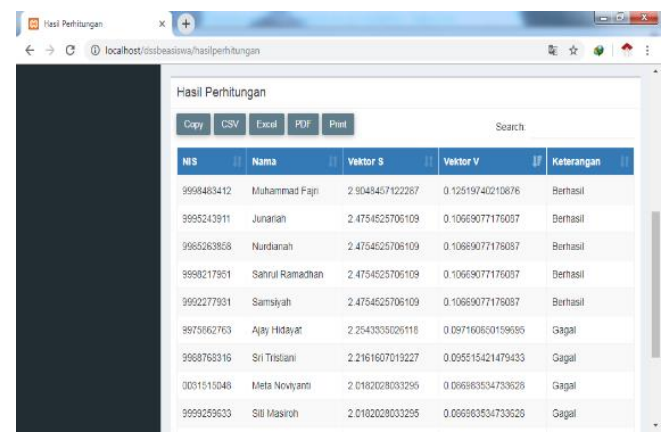

Figure 14. The calculation results
Figure 14 above explains the final results after inputting the student's identity, criteria and weights, sub-criteria and weights, carried out the conversion and determined the limits of success or failure. The rightmost column gives a sequence of success or failure of the student in getting a scholarship.

\section{Conclusion}

From the results of research, the authors have concluded that the weight product method can use as one method in developing a decision support system for scholarship recipients at the MA Al-Falahiyah Al-Asytari, by inputting data from students who submit scholarships to calculating grades based on criteria which have specified. As the development of this system, it expected not only to be web-based but also mobile-based.

\section{References}

Arief, M.R., 2011, Pemrograman Web Dinamis Menggunakan Php dan Mysql, Yogyakarta: Andi.

Khumiadi, A., Latifah, U., Rinawati, dan Taufiq, 2018, "Implementasi Weighted Product Pengklasifikasian Lahan Pertanian", JIIK ISSN: 2503-3832, Vol 4 No 1, April 2018, hal 13-18

Kusrini. (2007). Konsep dan Aplikasi SistemPendukung Keputusan. Yogykarta: Andi

Kusumadewi, S. et al. (2006). Fuzzy Multi-Attribute Decision Making (Fuzzy MADM). Yogyakarta: Graha Ilmu

Manik, A.R.S, Nurhadiyono, B., dan Rahayu, Y., 2015, "Implementasi Weighted Product (WP) Dalam Sistem Pendukung Keputusan Untuk Menyeleksi Peneria Beras Masyarakat Miskin (Raskin)", Techno.COM ISSN: 2356-2579, Vol 14 No 2, Mei 2015, halaman: 109-114

Murniasih, Erny. (2009). Buku Pintar Beasiswa. Jakarta: Gagas Media

Pressman, R S., 2002, Rekayasa Perangkat Lunak Pendekatan Praktisi (BukuSatu), Yogyakarta: Andi.

Septarini, RS. 2017. Penentuan Jumlah Produksi Shampo Dengan Fuzzy Inference System Sugeno : Studi Kasus PT. Guardian Pharmatama Tangerang. JIKA (Jurnal Informatika), Vol 1 No 2, September 2017.

Septarini, RS, Husain, SM. 2018. Rancang Bangun Aplikasi Customer'Ku Untuk Menentukan Kualitas Pelayanan Menggunakan Metode Simple Additive Weighting Pada Bengkel Nissan Datsun Cimone. Prosiding Seminar Nasional Teknologi Informasi dan Aplikasi Komputer SINTAK2018, Vol 2, 14 November 2018 
Sommerville, I., 2011, Software Engineering (Rekayasa Perangkat Lunak. Jakarta: Erlangga

Sucipto, B.H., Widjaja, A., 2019, "Penerapan metode Weighted Product (WP) Dalam Sistem Penunjang Keputusan Penentuan Pegawai Terbaik Pada Sub Bagian Kepegawaian Direktorat Jendral Pembangunan Kawasan Perdesaan Kemendesa RI", IDEALIS ISSN: 2684-7280, Vol 2 No 2, Maret 2019, halaman: 251-256

Sukamto, R.A., Shalahudin, M., 2014, Rekayasa Perangkat Lunak (Terstruktur dan BerorientasiObjek), Bandung: Informatika

Taufiq, R., Permana, AA., Cahyanto, T dan Adha, R,
2018, Sistem Pendukung Keputusan Penerimaan Karyawan Menggunakan Simple Additive Weighting Studi Kasus PT. Trafoindo Prima Perkasa. Jurnal Al-Azhar Indonesia Seri Sains dan Teknologi, Vol. 4. No. 4, September 2018.

Taufiq, R dan Sugiharto, A. 2011. "The Decision Support System Design Of Employee Performance Appraisal Using Analytical Hierarchy Process (AHP) Method", Proceedings of The 1st International Conference on Information Systems For Business Competitiveness (ICISBC) 